\title{
Anthropology over Aesthetics: On the Poetics of Movement and Multilingualism in Three Translations of Yuri Herrera's Señales que precederán al fin del mundo
}

\section{Introduction}

When Latin American literature is translated into Scandinavian languages, book covers and reviews often stress anthropological values over aesthetic ones, typically highlighting both where the author comes from and where the book is set (Alvstad, "Strategic Moves"). Books from Latin America are thus mainly made relevant because of their origin rather than their aesthetic value or literary innovativeness. In general, this anthropological highlighting invites readers to expect that fictional texts from Latin America and other former European colonies would provide facts, information and insight into geographic, cultural and social conditions, that is, to values associated with non-fiction rather than fiction.

The Scandinavian emphasis on anthropology takes place in the paratextual packaging of the books, both on the covers and in forewords, epilogues, advertisements and reviews, at times neutrally, at times with travel metaphors and cover illustrations reminiscent of holiday brochures, at times in exoticizing ways evocative of the discourse identified by Said some forty years ago as orientalism (Alvstad, “Antologizing," "Arguing," "Strategic Moves”; Refsdal; Senstad). Since this emphasis on anthropology is characteristic also of literature translated from Africa and Asia, it plays a role in bringing these rather diverse literatures from the Global South together into a genre that in Sweden is sometimes referred to as world literature (Alvstad, "Strategic Moves" 81). It is a conception of world literature that stresses origin rather than "circulation" (cfr. Damrosch 4) and that clearly appeals to a certain section of the marketplace and its associated demands for the postcolonial to be exotic (Brouillete; Huggan). When the seemingly factual and/or the exotic (however invented) is given priority over aesthetic singularity, the immense literary diversity within each of these huge continents runs the risk of being homogenized (Alvstad, "Arguing," "Strategic Moves").

Cecilia Alvstad, Stockholm University

๑ Open Access. () 2020 Cecilia Alvstad, published by De Gruyter. (cc) BY-NC-ND This work is licensed under a Creative Commons Attribution-NonCommercial-NoDerivatives 4.0 International License.

https://doi.org/10.1515/9783110673678-013 
The present essay will explore more deeply the issue of emphasizing anthropology over aesthetics through a contrastive textual study of a Latin American novel by the Mexican writer Yuri Herrera and three of its translations. The aim is to shed light on whether the translated text itself-that is, the literary text seen in isolation from its paratextual surroundings-also can be shown to prioritize anthropological (geographic, cultural, social, etc.) values over aesthetic values. The focus of the analysis is on how formal poetic features, such as neologisms, direct the readers' attention to two of the novel's dominant topics, the interconnected issues of movement and multilingualism. The method of analysis is closely related to Boehmer's concept of reception-based or readerly pragmatics, in which critical reading means to pay close attention to how specific literary structures shape the cognitive processes that direct our perceptions while reading (2-3).

Boehmer claims that literary texts in postcolonial studies have "tended to be read illustratively or symptomatically, as an instantiation of paradigms drawn from a range of extra-literary studies-such as cultural studies, diaspora studies, anthropology" (3). In order to examine how the translators dealt with some of the text's aesthetic layers that shape the literary exploration of specific topics, the present essay will compare poetic features of the original to those of three of its translations. An underlying assumption is that the poetics of the texts is what allows the readers to work with these topics in specific ways. Just like in Boehmer's recent Postcolonial Poetics, the focus is on

the text as something that is read, and on the heuristic power of literature as literature; specifically, on the verbal and structural dynamics, the poetics, through which our understanding of the particular postcolonial condition being represented (race, resistance, liberation, reconciliation, precarity, and so on) may be shaped and sharpened. (3, Boehmer's italics)

The present essay will thus pay close attention to aesthetic elements such as neologisms that are likely to cognitively structure readers' attention toward certain passages.

The analysis will refer to three linguistic traits that typically appear in translations when compared to their source texts, namely, simplification, explicitation and normalization. Some scholars have even suggested that these three phenomena are universal linguistic traits of all translations (Laviosa-Braithwaite 288). Simplification may be lexical, syntactic and stylistic, for example when a more general word is used instead of a more specific one. Explicitation means that the translated text is more explicit than the source text, as when it adds background information, repeats information and clears up ambiguities. Normalization refers to a standardization of the text into a more conventional form (288-290). 
The novel under scrutiny here is Yuri Herrera's Señales que precederán al fin del mundo (2010) (SP) and its translations into Norwegian (Tegn forut for verdens ende, 2016) (NO), Swedish (Tecken som föregår jordens undergång, 2016) (SW) and English (Signs Preceding the End of the World, 2015) (EN). There are three reasons for choosing precisely Señales, the first of which is its highly innovative style. Lisa Dillman, the English-language translator of Herrera's book, portrays this style in the following manner:

Yuri Herrera's prose ... exhibits a multitude of distinct characteristics, displaying great variations in what is always creative and often non-standard language: its rhythm and orality; a style that is elegantly spare; striking metaphors, which are often unusual but rarely jarring: a mix of registers both low and high-slang and colloquial-but also lyrical and eloquent, some rural and others urban and both often very Mexican (or very much of its border); and neologism, to name just some. (Dillman 109-110)

The present essay focuses on a few of the stylistic traits mentioned by Dillman, more precisely the ones that in one way or another have to do with creative and non-standard language and how they call the readers' attention to the topics of movement and multilingualism. As it is impossible to include and focus on every poetic trait, the analysis risks coming across as unfair to the translators. However, the idea of this essay is not to evaluate the work of the three translators, but rather to point out some of the effects that translation decisions might have for how the book, the author, the source literature and source culture may be perceived/shaped by readers of the translations. The essay thus inscribes itself within the cultural turn in translation studies (Bassnett and Lefevere).

Second, the three translators work for different publishers in different target cultures and hence face very different expectations when translating a text. Target culture expectations delimit the translator's range of action. Other factors that may affect how translators carry out their task include the strength of their position in the field, if they translate in order to make a living or if it is a hobby, and so forth. This essay will not dwell long upon such issues, since the focus is neither on the quality of the translations nor on explaining the choices made by the translators/publishers. For the same reason, this essay will not examine the possible influence of the English translation, which was published first, on the Swedish and Norwegian translations.

The third reason for choosing this particular novel is that it resists a factual anthropological reading. References to languages and the people who speak them are associative, as when the languages being spoken are variously referred to as las lenguas de acá (SP 19), lengua (SP 19) lengua latina (SP 19, 115), lengua gabacha (SP 39) and gabacho (SP 73). Although it is possible to argue that these names allude to real languages such as Spanish and English, the names of these 
languages are never spelled out. Likewise, rather than providing a completely realistic account of Mexico peppered with Mexican names of towns and villages, the novel creates a mythological space, as described in the blurb of the Spanish edition:

Yuri Herrera no escribe "simplemente" sobre México y la frontera, sino que crea su México a través de historias y leyendas del pasado y del presente. Y traza con exactitud el mapa de un territorio que es aún más gigantesco, hecho tanto de lo que está sobre la tierra y en lo real como de lo que está bajo ella y pertenece a lo mitológico, a las culturas precolombinas.

[Yuri Herrera does not "simply" write about Mexico and the border but rather creates his Mexico through stories and legends of the past and the present. And with exactness, he draws the map of an even more gigantic territory, which is made up of both what is above the earth and real, and of what is below it and belongs to the mythological, to the preColumbian cultures]. (Herrera, Señales blurb, my translation)

In other words, this is a novel that might have a lot to do with Mexican society and culture, but there are few, if any, explicit references to Mexico itself ${ }^{1}$. All places are referred to in vague terms as el Pueblo (SP 19), Ciudadcita (SP 12) and Gran Chilango (SP 27), which means that the setting does not clearly play into a segment of a country that exists outside of the fiction. Likewise, when the protagonist Makina crosses a river on an "enormous inner tube, like from a tractor" (EN 37), this crossing may be reminiscent of what a crossing of Mexico's northern border might look like, but the river is never named, the border is not explicitly mentioned, and there are no explicit references to the United States after she arrives on the other side. There are some implicit references, however, for example to an army base that could be a United States army base (SP 79, 89, 95-104). There is also a stadium in which a game is played that seems to be baseball. In Dillman's translation the description of the game reads:

1 A word explicitly referring to Mexico only occurs once: Toda la cocina es cocina mexicana (SP 64, “All cooking is Mexican cooking,” EN 58). It is a complex reference to foreign kitchens, suggesting that the food from all restaurants smells familiar, and that this is because the people preparing the food, just like the people working as dishwashers, builders, florists, loaders, etc., are "countrymen" (paisanaje, SP 63). It is thus hinted that Makina is Mexican or at least that she knows Mexico well. This hint is made more explicit in the English translation since paisanaje-which in Spanish bears the two meanings of "countrymen", as either someone from a rural area or someone from the same country-is translated into "compatriots" (EN 57), which unambiguously bears only the second of these two meanings. Likewise, allá (SP 63), meaning "there", is translated into "back home" (EN 57) which explicitates that "there" is "home." This is made similarly explicit in the Swedish and Norwegian translations of this passage. 
Every week the anglos play a game to celebrate who they are. He stopped, raised his cane and fanned the air. One of them whacks it, then sets off like it was a trip around the world, to every one of the bases out there, you know the anglos have bases all over the world, right? Well the one who whacked it runs from one to the next while the others keep taking swings to distract their enemies, and if he doesn't get caught he makes it home and his people welcome him with open arms and cheering. (EN 59-60)

These descriptions certainly allude to the United States, but the country is not explicitly identified as such. However, although most geographic and cultural references throughout the novel are equally vague, the blurbs of all three translations, as well as Dillman's abovementioned epilogue, explicitly highlight that the plot is set in Mexico and the United States and on the border in between ${ }^{2}$. The novel's geographic setting is thus made much more explicit in the paratexts of the translations than it was in the original. Independently of any textual changes within the literary text itself, these paratexts will most probably prime readers of the translations to read them as a depiction of "reality" rather than mythical allegory. Moreover, the baseball scene excerpted above contains an example of a textual decision that might bring the translated text closer to "reality." The word "anglos" in the quote signals an association to people speaking English. Gabachos, the word Herrera uses in Spanish, is slightly more ambiguous. According to the crowdsourced Urban Dictionary, gabachos in the Mexico-United States context is a "chicano pejorative term for an English-speaking, non-Hispanic," but the word has also other meanings in Spanish. In Spain it is a pejorative way of referring to the French; according to the dictionary of the Royal Spanish Academy, it stems from gavach, which in Occitan refers to someone who does not speak well. The word gabacho thus plays into a scheme of spatio-linguistic ambiguity and vagueness that in the original contributes to a de-geographizing of the setting of the novel, which is neither a complete allegory nor a literary space with a completely clear counterpart in reality. It seems to say simultaneously that the setting is North America (Mexico and the United States) and that it might be elsewhere, thus anchoring the topics of movement of people and multilingualism that the novel explores within a much larger context.

Similarly, although this is clearly a book that features migration, this topic is not referred to with conventional words, such as "migrant," "migration" and "border." It is a literary investigation of the topic that works with neologisms and refrains from stereotypical language and typecast representations. Overall, this novel does not therefore lend itself easily to "strategic exoticism" (Huggan). Thus,

2 The Swedish blurb even mentions Mexican macho culture, which has been shown to already have been textually and paratextually reinforced in translations from the 1960s, that is, in some of the first Scandinavian translations of Latin American literature (Refsdal). 
it is not an immediate example of the anthropological-geographical translation strategies that this essay sets out to examine. Then again, if the target culture strongly expects Latin American literature to be about Latin America in a way that provides factual knowledge and some exotic elements, then it might be that the translators perceive and adapt to such expectations by adding such features.

\section{Movement}

Herrera's novel explores diverse issues related to the movement of people, and it is therefore not surprising that one of the most conspicuous neologisms in the book is a movement verb. An invented word, the meaning of which the reader has to figure out, is a poetic device likely to cognitively call attention to the topic of movement in the novel, thus constituting one of the central themes for the reader. In the Spanish text this invented verb is jarchar as in Jarchó a la calle (SP 38) and apenas jarchó del agua (SP 41). Dillman translates these two examples into "She versed to the street" (EN 36) and "as soon as he was out of the water" (EN 38). In Herrera's Spanish text jarchar is a frequently used verb-it appears on most pages of the book-and as such it will soon establish itself as a verb of movement to the reader.

Dillman generally translates jarchar into her English neologism "to verse." From the context this is clearly also a motion verb in English. The meaning of the word is moreover strengthened by its semantic similarity to the existing verb "reverse," moving backward. Dillman comments on her decision to translate jarchar into "verse" in an epilogue that follows the translated text. She decided on the word since, like jarchar in Spanish, it is a "noun-turned-verb" (113) and since itjust like the Spanish word-has a connection to poetry. As those acquainted with the Spanish literary tradition will be aware, jarchas are the last lines of Arabic or Hebrew poems written in Al-Andalus. Dillman (112) explains that the word comes from the Arabic kharja, which means "exit". In contrast to the rest of the poem, these last lines would be written in Mozarabic, the Romance vernacular spoken at the time in what is now southern Spain.

The Norwegian and Swedish translators, instead of creating a neologism, normalize jarchar into existing movement verbs that are not at all stylistically notable:

NO (29): Hun gikk ut på gata [She went out into the street]

SW (37): Makina gick ut [Makina went out]

NO (31): da han hadde kommet seg opp av vannet [when he had come out of the water]

SW (39): så fort han kommit upp ur vattnet [as soon as he (had) come out of the water] 
The Norwegian and the Swedish translations here simply say that Makina went out (to the street) and that he (Chucho) came out of the water. The deviant language is gone. A reader who only reads the translation and not the Spanish text will not have a chance to know that it was ever there. This normalization of Herrera's neologism means that there is nothing in this part of the text that may draw the readers' attention to the way the translated text has been formulated. A neologism would have involved a higher risk in this sense, since the translator could have been perceived as being too influenced by the source language or, even worse, as not being proficient in the target language. The very fact that Dillman, who chose to translate jarchar as "verse," comments extensively on this decision in the epilogue may be her way of regaining some of the readers' "trust" that she may have lost by using a non-existent verb (Alvstad, "Translation Pact”). In the Norwegian and Swedish translations, although the translators have eliminated one of the most talked about stylistic features of Herrera's novel, there is nothing in the translated text itself that can make the reader suspicious of such a translation loss.

From an ethical perspective and using the terminology established by Andrew Chesterman (175-191), the values of trust and clarity have won over the values of truth and understanding, where truth concerns the relationship to what is actually said in the source text. Although both the Norwegian and Swedish text is clear, the not so "truthful" handling of these and similar instances of the verb jarchar may in fact obfuscate the understanding of the novel as a whole, or at least take this understanding along new routes. Two examples will illustrate this point. As already mentioned, Herrera's novel deals with people on the move, without using words typically related to migration, such as migrante, migrar or frontera. If not immediately conspicuous by their absence, the frequently used neologism jarchar, which precisely indicates movement, may serve to draw attention to this absence. The fact that the word jarchar furthermore has its roots in Al-Andalus, a cultural context well-known for its many coexisting languages and cultures at a time before the Mozarabic language had even developed into Spanish, widens the reader's perspective on the idea of human beings in movement well beyond the Mexico-United States context. The normalization of the verb into standard language is thus not primarily merely a downplaying of a creative word formation. It has much broader implications for the possible interpretations of the novel as a whole, since it also downplays its intertexts and the historic and geographic contexts they bring in. Moreover, by erasing an important pointer to what is absent, it downplays the allegoric and mythological in favor of the immediately understandable. There is of course a limit to what can be achieved in translation, and Dillman's solution using 
"verse" must in this context be considered a relatively fortunate manner of conveying many of the hidden and open meanings of the Spanish neologism, and although Dillman uses "verse" less than Herrera uses jarchar-see for example the above-quoted normalization "as soon as he was out of the water" (EN 38)it succeeds significantly in reproducing the poetic idea of movement that is lost in the Norwegian and Swedish translations.

With regard to the absence of prototypical words related to migration, this absence is not paralleled by a corresponding absence in any of the three translations. In the following example, taken from the English translation, the word "migrants" is used as a counterpart to the more specific and marked transterrados (from trans, meaning "at the other side of" or "through," and tierra, meaning “earth," "region” or "country”):

SP (76): Dos o tres recados les había hecho llegar su carnal con sendos transterrados a su vuelta. [Her relative had caused two or three messages to reach her/them, each by a transplanted person on their return.] (My underlining, here and in subsequent quotes.)

EN (68): Her brother had sent two or three messages back with assorted migrants on their way home.

The rhetorical device of not using certain words is thus eliminated in this translation. Another difference between the two sentences above is that Dillman explicitates that the returning people are "on their way home" when the Spanish only says a su vuelta ("on their return"). Dillman thus emphasizes where these transterrados belong, where their real homes are.

Like Dillman, the two Scandinavian translators use the morpheme "migrant" to translate transterrados as, respectively, the standard Norwegian word emigranter ("emigrants") and the invented Swedish word transmigranter ("trans-migrants"), the latter thus borrowing a word from the title of another of Herrera's books La transmigración de los cuerpos (The Transmigration of Bodies):

NO (59): Broren hennes hadde sendt to eller tre beskjeder med emigranter på vei hjem. [Her brother had sent two or three messages with emigrants on their way home.]

SW (74): Makinas bror hade skickat två eller tre meddelanden till dem med olika hemvändande transmigranter. [Makina's brother had sent them two or three messages with different home-returning trans-migrants.]

All three translations thus explicitate the word "migrant," which is not used in the source text, and furthermore explicitate "home" (Norwegian hjem and Swedish hem in hemvändande, a noun+verb compound meaning something like "home-returning"). 
The word transterrados merits further comment, since its meaning, in fact, is not only that of "migrants." It was coined by the Spanish philosopher José Gaos (1900-1969), who fled to Mexico as an exile in 1939 and remained there for the rest of his life. Gaos' neologism transterrado allowed him to make a distinction between this and the already existing concept of desterrado. While the dictionary definition of desterrados refers to those who have to leave their country for a foreign one, transterrados refers to those who find that they can make the new country their home. The word transterrados has not yet made it all the way to the dictionary of the Royal Spanish Academy, but it is nonetheless used in Spanish, recently as the title of a novel published in Spain by the Colombian author Consuelo Triviño Anzola ${ }^{3}$. The choice of “migrants" normalizes Herrera's choice of word into a more standard form and it is also a simplification, since it uses a more general word for a more specific one. This may make the meaning clear, but it also alters the aesthetics of Herrera's prose, explicitly spelling out a word that is not used in the source text. It further means that the intertextual connection that transterrados has to the philosophical work of José Gao is severed, and since Gao himself was one of many Spanish intellectuals who became exiles in Mexico during the Franco regime, there is also a loss of the connection to this context to Mexico as a host country for political migrants.

A similar example where there is also a loss of intertext is the translation of éxodo multitudinario (SP 36), which Dillman renders as "mass exodus" (EN 34). Exodo and "exodus" both refer to the emigration of a large amount of people, and they are both also the name of the second book of the Old Testament, in which Moses helps his people escape from slavery in Egypt across the Red Sea. The word thus intertextually anchors the idea of people having always been on the move away from unfair living conditions and persecution. In this sense its function is similar to jarcha, which suggests Al-Andalus, and transterrados, which in turn suggests the Spanish anti-Franco intellectuals who fled to Mexico. "Mass exodus" (EN 34) reproduces this intertextual connection and thus the historical dimension, but it interestingly changes multitudinario, which is a neutral or even slightly positive way of denominating a large group of people, whereas "mass" rather is slightly negative, especially when combined with a word related to migration. Although a minor change, it may play into such negative stereotypical preconceptions of migration that Herrera's novel in Spanish seems to question.

3 See https://www.letraslibres.com/mexico-espana/filosofia-la-filosofia and https://elpais. com/diario/1989/08/28/opinion/620258410_850215.html for two examples of the word and a discussion of its origins. See https://www.proceso.com.mx/556604/los-transterrados for a recent example of the word being used in relation to Mexico-United States migration (24/10/ 2018). 
The Norwegian and Swedish translations, however, normalize éxodo multitudinario as masseutvandring ("mass emigration," NO 28) and väldig folkvandring ("enormous migration of people," SW 34), with utvandring and vandring in Norwegian and Swedish being Germanic synonyms of "emigration" and "migration." The most common way of referring to immigrants in Norwegian and Swedish is in fact by the Germanic words innvandrer and invandrare ("immigrant"), respectively, rather than the Latinate immigrant. Thus, although the morpheme migrant is not being used here, the translations certainly involve the most common way of referring to migration in Swedish. The two translations de-historicize Herrera's formulation, since the intertextual link to the movement of people in the Bible is broken. A possible explanation for not using the word "exodus" may be that the translators opted for clarity, since exodus may be a less-established concept in Scandinavia than in North America, given that the Book of Exodus in Norwegian and Swedish is known rather as "the Second Book of Moses" (Andre Mosebok and Andra Moseboken, respectively). The Swedish text also adds folk ("people") to folkvandring, which in Swedish connotes another historical context, namely the turbulent Migration Period of late antiquity, that is the Germanic invasions of around 350-600 CE, potentially therefore priming the idea of "invasion" in the reader rather than the Exodus-related idea of leaving a situation of slavery.

Finally, the Norwegian choice of masse is similar to "mass" in English, although its common usage together with the word innvandring ("immigration") by Norwegian politicians who are hostile to immigration may make its semantic prosody even more negative in Norwegian than in English ${ }^{4}$. Väldig in Swedish, meaning "enormous" or "huge," is in contrast value-neutral.

Returning now to how the seemingly clear handling of the verb jarchar in Norwegian and Swedish may obfuscate the understanding of the novel as a whole, a second example will illustrate this point. This takes us to the end of the novel, its exit, or jarcha, where the word Jarcha, now a noun, appears on a sign over a door, and then twice in the following sentences. In Spanish and English this section reads:

SP (117): Sobre la puerta había un cartel que decía Jarcha. Trató de recordar cómo se decía jarcha en alguna de sus lenguas pero no lo consiguió. Ésta era la única palabra que se le venía a los labios. Jarcha. [Over the door was a sign that said Jarcha. She tried to remember how to say jarcha in any of her languages but couldn't. This was the only word that came to her lips. Jarcha.]

4 Cfr. this usage at https://www.rights.no/tag/masseinnvandring/. 
EN (105): Over the door was a sign that said Verse. She tried to remember how to say verse in any of her tongues but couldn't. This was the only word that came to her lips. Verse.

The verb jarchar has been used throughout the novel, a novel written in Spanish, and this passage clearly indicates that it is not a word that Makina, the multilingual protagonist who speaks and interprets for others between lengua, lengua latina and lengua gabacha, recognizes from any of the languages she knows. There is a twist here that underscores that none of the languages spoken in the novel is Spanish. There are textual features that have invited readers to identify the space of the second part of the book with the United States, but these indices are here followed by a decontextualization from any existing geographic and anthropological "reality." The space is again clearly mythological and not the least socio-realistic.

This is all well-reproduced in Dillman's translation, as is the connection to poetry. Lost, however, are the connections to the multilingual and multicultural Al-Andalus with its multilingual poetry-there are limits to what translation can do. The Norwegian and the Swedish translators, however, run into bigger problems. Since they normalized jarchar into standard Norwegian and Swedish, they have no neologism they can draw upon here. The Swedish translator solves this problem using the foreign word jarcha in italics in her text:

SW (117): Ovanför dörren hängde en skylt där det stod Jarcha, utgång. Makina försökte dra sig till minnes hur man sa jarcha på något av de språk hon talade, men kunde inte. Det enda ord som dök upp på hennes tunga var jarcha. [Over the door hung a sign saying Jarcha, exit. Makina tried to remember how one said jarcha in any of the languages she spoke, but she could not. The only word that appeared on her tongue was jarcha.]

This is a rather verbatim translation from the Spanish, with one exception, the explicitation of the meaning of jarcha the first time it is used. The translator then adds a comma and the word utganng ("exit"). A problem with this translation is that it is rather unclear who the utterer of utgaing is. The seeing of the sign is focalized through Makina, the narrator being responsible for the utterance. But is the narrator also the one who provides the translation of what jarcha means? It comes across as illogical that the narrator suddenly, in a passage focalized through Makina, would provide information to the readers over the head of the character. It would however be even more illogical if Makina would know the meaning of this word since the text clearly says that she cannot remember what it is in any of the languages she speaks. The word could also be attributed to the translator, as a kind of translator's note inserted more or less ostentatiously into the translated text. Or it could be attributed to the author, who in this case would come across as 
a bad writer who did not know how to be consistent with the voices and perspectives he created.

The Norwegian translator opts for another solution:

NO (91): Over døra hang det et skilt. Jarcha, sto det-Utgang. Hun forsøkte å finne et godt ord for jarcha, avferd og endelikt, på språkene hun kunne, men klarte det ikke. [Over the door hung a sign. Jarcha, it said-Exit. She tried to find a good word for jarcha, departure and ending, in the languages she knew, but she did not succeed.]

Utgang means "exit," avferd "departure” and endelikt "ending” or even "death." This means that the translator spells out three of the words that Makina cannot find, but in contrast to the Swedish text, the internal logic of the text in Norwegian still works. This is because the translator changes more details. What the Norwegian text says is that she tried to find a good word for jarcha, but that she did not succeed, so that the three words for jarcha that appear in the text become tentative approximations. Furthermore, the Norwegian translator omits the following two sentences, which say that jarcha was the only word that came to mind ("Ésta era la única palabra que se le venía a los labios. Jarcha.”), and the problem is solved. It is not a truthful representation of what the original says, and it furthermore certainly alters the poetics of the text, but it is a solution that has an internal logic. This warrants the trust the reader has in the translator and also the author, whereas an illogical translation solution would have exposed not only the translator but also the author to potential criticism and distrust.

Before leaving the discussion of jarcha altogether, it may be noted that the fact that this word appears once in the Norwegian and Swedish texts makes the connection to Al-Andalus present in their translations. Very few Norwegian or Swedes would, however, be able to pick up this reference. Not many Scandinavians are acquainted with Mozarabic poetry, and those who are would probably choose to read Herrera's novel in Spanish and not in translation. Although formally retained in the text, this allusion to the final lines of multilingual poetry from the past must therefore be considered more or less lost in translation.

\section{Multilingualism}

The setting of Señales is multilingual, but unlike many recent works of Chicano literature by authors such as Gloria Anzaldúa, Ana Castillo and Sandra Cisneros, there is no English-Spanish hybridity in Herrera's prose. The multilingual setting is instead constructed via other techniques such as a number of reflections on multilingualism and code-switching (e.g. SP 73-74), as well as through the 
constant usage of slightly twisted or invented expressions such as lengua latina (SP 115) and lengua gabacha (SP 39), which, although alluding to a multilingual Mexico-United States setting, does not turn the text into a Spanish-English multilingual text, since it is all written in Spanish. The following is an example of a passage in which multilingualism is brought to the fore in the novel:

SP (74): Al usar en una lengua la palabra que sirve para eso en la otra, resuenan los atributos de una y de la otra: si uno dice Dame fuego cuando ellos dicen Dame una luz ¿qué no se aprende sobre el fuego, la luz y sobre el acto de dar? No es que sea otra manera de hablar de las cosas: son cosas nuevas. Es el mundo sucediendo nuevamente, advierte Makina: prometiendo otras cosas, significando otras cosas, produciendo objetos distintos.

EN (66): Using in one tongue the word for a thing in the other makes the attributes of both resound: if you say Give me fire when they say Give me a light, what is not to be learned about fire, light and the act of giving? It's not another way of saying things: these are new things. The world happening anew, Makina realizes: promising other things, signifying other things, producing different objects.

This section describes one of the other ways in which Herrera creates the multilingual setting, that is, by using calques, also called direct translations, from English in his Spanish, or what in the quote above is described as "using in one tongue the word for a thing in the other."

Dillman's English translation closely follows the Spanish text here, as do the Norwegian and Swedish translations of the same passages. The slightly twisted expressions such as lengua latina and lengua gabacha, conversely, seem to create more of a challenge for the translators. As mentioned in the introduction to this essay, Dillman chooses to translate gabacho with "anglo," as in the following example, which also provides the Norwegian and Swedish translations of the same sequence:

SP (68): y en gabacho decían Frescos. [and in Gabacho they said We're cool]

EN (62): and in anglo said We're cool.

NO (52): og sa på gabacho: We're good. [and said in Gabacho: We're good]

SW (67): och på gabacho konstaterade Det är lugnt. [and in Gabacho said It is cool]

As mentioned before, "anglo" has a narrower meaning in the English language than gabacho has in Spanish, as it only could refer to people speaking English, with the original Spanish meaning of the word gabacho, which refers to the French and Spanish-French border context, being lost. Then again, this original meaning may not be known to Spanish-speakers in Mexico and the United States.

Moreover, in the Spanish original, gabacho, lengua latina and so forth are invented languages, or at least the invented names of languages, i.e., they do exist as languages in the fictional world. From this point of view, they should have been 
capitalized in English, but they are not. They appear in the English translation as "anglo," "anglo tongue" and "latin tongue" and therefore do not seem to be the names of languages, but paraphrases. This interestingly enough contributes to making them more identifiable with English. By not capitalizing the "a," the translation seems to communicate that the language English is referred to in this text with the circumlocution "anglo," rather than Anglo being a language of its own.

The Norwegian and the Swedish keep gabacho, using italics, which at first sight may seem to reproduce the aesthetics of the source text to a higher degree. The opposite may actually be the case, however, since the Norwegian translation uses the English phrase "We're good" to represent what is being said in Gabacho, thus suggesting that Gabacho is English. Since the word gabacho at the same time appears in Spanish, the Norwegian translation thus introduces a multilingual code (Norwegian, English and Spanish) that does not have a counterpart in Herrera's text in Spanish, which consistently makes use of a monolingual and not a bilingual or multilingual code.

There is a similar example further on in the book in which the characters are speaking Gabacho:

SP (102): Primera base, ¿eh? ¡Bien por ti! [First base, huh? Good for you!]

EN (92): First base, huh? Good for you!

NO (78): First base hæ? Bra for deg! [First base huh? Good for you!]

SW (100): First base, va? Du har tur, du! [First base, huh? You are lucky, you!]

In the Spanish text the language Gabacho is always represented in Spanish, possibly with the exception of a "Hey" used to call someone's attention (SP 50). In the above examples, however, the Spanish primera base is a calque of an American conventionalized baseball metaphor for "a preliminary stage of sexual intimacy, typically characterized as kissing" (Oxford Dictionary of English, Apple 2.2.2). The English translation does not in any way represent this, since translated back into English, the Spanish neologism is again conventionalized (a translation challenge indeed difficult to resolve). The Norwegian and the Swedish translations manifest the Englishness of the expression by representing it in English. Thus, they explicitate that Gabacho is English and shift the text from the monolingual to the multilingual. In the above example, they also eliminate Herrera's stylistic device of using a calque from the English, which, as mentioned above, is one of the devices he uses to build up the multilingual setting.

When the Norwegian and Swedish translators introduce a multilingual code into Herrera's novel, they in fact draw on a much-used device in the abovementioned Chicano writing as well as in the fairly recently translated-and much talked about-The Brief Wondrous Life of Oscar Wao by Junot Diaz. This can be 
analyzed as an aesthetic stereotyping in which the singularity of this works gets lost, in favor of what seems to be an expectation of a larger body of works.

Not only gabacho but also lengua latina seems to create problems for the translators. The Norwegian translator faces this challenge by varying the ways he translates it. Among the less fortunate solutions are translating it into spansk ("Spanish," NO 52) and latino ("Latino," NO 74), thus again explicitating realworld correspondences for a fictional language (or, if not an invented language, at least a language with an invented name).

On another occasion, the Norwegian translator opts for hennes eget språk ("her own language," NO 89), thus singling out lengua latina as Makina's own. The original, however, never spells out that lengua latina is Makina's first language. Early on in the Spanish version of the text, it is even possible to infer the opposite, that is, that both lengua latina and lengua gabacha are second languages for Makina. In a sequence that describes Makina's work as an operator of the only telephone in the neighborhood, the three languages are depicted in the following way, suggesting that the language that might be closest to her is the language here referred to as just lengua ("language"):

SP (19): A veces era gente de pueblos de por ahí la que llamaba y ella contestaba en lengua o lengua latina. A veces, cada vez más, llamaban del gabacho; éstos frecuentemente ya se habían olvidado de las hablas de acá y ella les respondía en la suya nueva. Makina hablaba las tres y en las tres sabía callarse. [Sometimes it was people from villages nearby who called and she answered in Language or Latin Language. Sometimes, more and more, they called from the Gabacho, those frequently already had forgotten the ways of speaking from here and she answered them in their own new one. Makina spoke all three and in these three she knew how to keep quiet.]

EN (19): Sometimes they called from nearby villages and she answered them in native

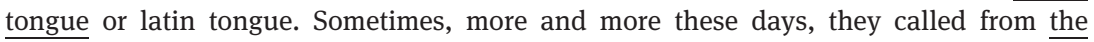
North; these were the ones who'd often already forgotten the local lingo, so she responded to them in their own new tongue. Makina spoke all three, and knew how to keep quiet in all three, too.

NO (15): Iblant ringte det folk fra andre landsbyer, og hun svarte på dialekt eller på vanlig spansk. Iblant, og det skjedde stadig oftere, ringte folk nordfra. Det var dem som hadde glemt den lokale dialekten, så hun svarte på det nye gringospråket deres. Makina snakket alle tre språkene, og kunne også holde munn på alle tre. [Sometimes people called from other villages, and she answered in dialect or in ordinary Spanish. Sometimes, and this happened ever more often, people called from the North. It was they who had forgotten the local dialect, so she answered in their new gringo language. Makina spoke all three languages, and she also knew how to keep her mouth shut in all three].

SW (17): Ibland var det folk från byarna i närheten som ringde och då svarade hon på det egna språket eller på det latinska. Ibland, allt oftare, ringde de norrifrån; och då hade de för det mesta glömt traktens språk, så hon svarade på deras nya. Makina talade alla tre och på alla tre kunde hon hålla tyst. [Sometimes it was people from the villages nearby 
who called and then she answered in the own language or in the Latin one. Sometimes, more and more often, they called from the North; and then they had more often than not forgotten the language(s) of the neighborhood, so she answered them in their new one. Makina spoke all three and in all three she knew how to keep quiet.]

Lengua is just "language" without further definitions and the way it is used here can be considered deviant from a linguistic and stylistic point of view. All three translators, however, normalize this deviant usage of lengua. The English and Norwegian translations, by specifying that it was her "native tongue" or dialekt ("dialect"), respectively, eliminate the possibility of inferring that this is Makina's first language, while the Swedish translation explicitates that this is indeed her first language, or det egna språket (literally, "the own language").

Another important difference between the translations and the original is underlined above. All three translations mention the North (nordfra and norrifrån in Norwegian and Swedish). This again adds a geographic explicitness that may not be as obvious in the Spanish text.

The Norwegian translator in this quote moreover specifies that the people who went to the North speak not only a new language, but det nye gringospråket deres ("their new gringo language"). A similar explicitation appears some pages further on, when gabacho is followed by the addition of gringoenes språk ("the language of the gringos"). This may be a compensation for what is lost in the translation of the word gabacho, since Norwegian readers will not know that gabacho, in the Spanish spoken in the United States and Mexico, is similar to what in Norwegian is referred to as gringo. As a consequence, however, the deviant and innovative language-a building element crucial to Herrera's prose-is compromised.

All three translations make use of Spanish words, for example the word pulque early on in the book when Makina is offered this drink at a bar (SP 17-18), the word jefecita for mother (SP 48) and Doña (SP 83) as a way of addressing a woman. From the context it is quite obvious that pulque is an alcoholic beverage. It is also clear that jefecita is the mother and that Doña is well-known as a form of address-if not understood, it would probably be taken for a proper name. There is in other words no need to provide a translation to improve clarity. Dillman writes in the epilogue to her translation that she retains some words in Spanish as "a linguistic reminder to the reader that this is, in fact, a translated text" (112). This seems clear-cut and is furthermore consistent with the ethical approach to translated texts advocated by, for example, Lawrence Venuti. However, foreign words in translations are not only innocent reminders of the text being translated but would also generally signal a foreign setting. When it comes to the translation of this novel, the words in Spanish specify the geographic-linguistic context as being precisely Spanish-speaking. 
The Norwegian translation uses more expressions in Spanish than the other two. It also explicitates early in the book that the characters are speaking to each other in Spanish by letting the last words of what a character says appear in Spanish in the Norwegian translation:

NO (13): så ber du meg om hjelp, og jeg, jeg sier claro que sí [and you ask me for help, and I, I say claro que sí]

SP (17): me estás pidiendo ayuda y yo, mírame, te digo claro que sí

The Spanish text here is all in Spanish and the other two translations use monolingual English (EN 17) and Swedish (SW15), respectively, without any mixing of two linguistic codes. The device of using Spanish in the Norwegian text here, rather than telling the reader what language the book is translated from, serves to show the reader that the characters are speaking Spanish to each other. However, as has been made clear above, it is in fact not stated in the original that the characters are speaking Spanish. Spanish is used to represent all languages in the original text. In this sequence the characters could be speaking lengua or lengua latina, but neither of these is in fact identified as being Spanish, and in this sense the novel as a whole is in fact a fictional translation.

\section{Conclusion}

Movement and multilingualism are central themes throughout Señales and its translations into English, Norwegian and Swedish. The comparison of the four texts has shown, however, that there are important differences to how these themes are built up in each text. The Spanish text includes a number of neologisms such as jarchar and jarcha that draw attention to the theme of movement. The creative names of languages and the people who speak them (lengua, lengua latina, lengua gabacha, etc.) puts the focus on multilingualism. The words jarcha, gabacho, transterrado and éxodo furthermore place the themes of movement and multilingualism in a wide historic setting that includes the Bible, AlAndalus and the exile of Spaniards in Mexico during the Franco regime. Moreover, there are important absences in the Spanish text, such as stereotypical words referring to migration (migración, migrante, frontera, etc.), which also work as a poetic device to put the theme in focus. In the original there are furthermore very few cues that point particularly to North American historic or cultural circumstances, there being, for example, no names of languages and villages with an exact counterpart in the real world. When cultural phenomena such as baseball are implied, they are generally not mentioned by their names, 
and there is thus a vagueness and ambiguity surrounding even the most obvious references to real-world cultural or geographic circumstances.

In the translations this does not work in the same way, since many of the translation solutions undeniably bring the literary text closer to reality. The fictional language Gabacho is, for instance, made more identifiable with English in all three translations. The English translation does this by naming the fictional language "anglo," while the Swedish and Norwegian translations use English phrases a few times when it is clear from the novel that Gabacho is being spoken. The Norwegian furthermore explicitates that lengua latina is Spanish. The way the neologisms and the concepts they represent are translated thus brings the setting to a North American geographic and cultural context.

The use of pulque, jefecita and other Spanish words in the translations furthermore reinforces this geographical setting. Dillman comments in her epilogue that she left these words in Spanish as a reminder that the text is a translation. This is consistent with the ethical approach to translated texts advocated by, for example, Lawrence Venuti. This essay has, however, shown that the Spanish words in the translations are not innocent reminders of the text's status as a translation, since they also add a specification of the geographic-linguistic context as being precisely Spanish-speaking. The question that arises is therefore whether interweaving words from the source language into the translation, thus anchoring the translated text in its source culture, can be considered ethical when the novel itself so distinctly resists a multilingual linguistic code, when the languages are not identifiable as real languages, and when the cultural and geographic setting is ambiguous.

Various poetic devices, such as neologisms and lexical silences, surround the themes of movement and multilingualism in the original, but were flouted in the translations. From a technical point of view, the translators normalized, explicitated, and simplified, that is, they created linguistic features that are very common in translations. The effects of these processes of normalization, explicitation and simplification were here shown to weaken important aesthetic layers of Herrera's text, while at the same time reinforcing the anthropological setting as being Mexico, the United States and the border between them. While previous studies of Scandinavian translations of Latin American literature have shown that book covers and reviews stress anthropological over aesthetic values, this study has demonstrated that this also takes place in the literary text itself, seen in isolation from its paratextual surrounding. 


\section{Works cited}

Alvstad, Cecilia. "Anthologizing Latin-American Literature: Swedish Translative Reimaginings of Latin America 1954-1998 and Links to Travel Writing.” Anglo-Saxónica, vol. 3, 2012, pp. 39-68.

--.. "Arguing for Indirect Translations in Twenty-First-Century Scandinavia." Translation Studies, vol. 10, no. 2, 2017, pp. 150-165. doi:10.1080/14781700.2017.1286254.

-.-. "The Strategic Moves in Paratexts: World Literature Through Swedish Eyes." Translation Studies, vol. 5, no. 1, 2012, pp. 78-94.

--.. "The Translation Pact." Language and Literature, vol. 23, 2014, pp. 270-284.

Bassnett, Susan, and André Lefevere (eds). Translation, History and Culture. Pinter, 1990.

Boehmer, Elleke. Postcolonial Poetics: 21st-Century Critical Readings. Palgrave Macmillan, 2018.

Brouillete, Sarah. Postcolonial Writers in the Literary Marketplace. Palgrave Macmillan, 2007.

Chesterman, Andrew. Memes of Translation: The Spread of Ideas in Translation Theory. Benjamins, 1997.

Damrosch, David. What Is World Literature? Princeton University Press, 2003.

Dillman, Lisa. "Translator's Note." Signs Preceding the End of the World. Yuri Herrera. And Other Stories, 2015, pp. 109-114.

Herrera, Yuri. Señales que precederán al fin del mundo. 2nd ed. Periférica, 2010.

---. Signs Preceding the End of the World. Trans. Lisa Dillman. And Other Stories. 2015.

--.. Tecken som föregår jordens undergång. Trans. Maria Cederroth. Nilsson, 2016.

--.. Tegn forut for verdens ende. Trans. Christian Rugstad. Cappelen Damm, 2016.

Huggan, Graham. The Postcolonial Exotic: Marketing the Margins. Routledge, 2001.

Laviosa-Braithwaite, Sara. "Universals of Translation." Routledge Encyclopedia of Translation Studies. Ed. Mona Baker. Routledge, 2001, pp. 288-291.

Refsdal, Eva. When "a girl" Becomes "an attractive little number": Stereotyped Representations of Latin America in Literary Translation and Reception in 1960 s Norway. University of Oslo, PhD dissertation, 2016.

Said, Edward, W. Orientalism. Pantheon Books, 1978.

Senstad, Idun Heir. "Bokomslag som formidling: Cubanske romaner i norsk innpakning."

Litteratur-og kulturformidling: Nye analyser og perspektiver. Eds. Helge Ridderstrøm and Tonje Vold. Pax, 2015, pp. 166-188.

Venuti, Lawrence. Translation Changes Everything: Theory and Practice. Routledge, 2013.

--.. The Translator's Invisibility: A History of Translation. 2nd ed. Routledge, 2008. 
